\title{
Production of N-acetylglucosamine from shrimp shells' chitin using intracellular chitinase from Mucor circinelloides
}

\author{
1,"*Halim, Y., ${ }^{1}$ Fransiska, ${ }^{1,2}$ Hardoko and ${ }^{1}$ Handayani, R. \\ ${ }^{1}$ Food Technology Department, Universitas Pelita Harapan, Jl. M.H. Thamrin Boulevard, Lippo Karawaci, \\ Tangerang 15811, Indonesia \\ ${ }^{2}$ Faculty of Fisheries and Marine Sciences, Universitas Brawijaya. Jl. Veteran No. 1 Malang 65113,
} Indonesia

\author{
Article history: \\ Received: 29 March 2020 \\ Received in revised form: 4 \\ May 2020 \\ Accepted: 15 May 2020 \\ Available Online: 30 May \\ 2020
}

\section{Keywords:}

Chitinase,

Chitin,

Intracellular,

Mucor circinelloides,

$\mathrm{N}$-acetylglucosamine

DOI:

https://doi.org/10.26656/fr.2017.4(5).135

\begin{abstract}
Chitin is a natural biopolymer found in shrimp shells and can be processed into Nacetylglucosamine which is extensively used as a dietary supplement to treat osteoarthritis, back pain and knee pain. This research was conducted to determine the optimum $\mathrm{pH}$, temperature, substrate concentration and incubation period to produce $\mathrm{N}$ acetylglucosamine using crude and semi pure intracellular chitinase extracted from Mucor circinelloides. Chitinase activity was measured to determine optimum $\mathrm{pH}$ and temperature by using various pHs $(3,4,5,6,7,8$ and 9$)$ and temperatures $\left(30^{\circ} \mathrm{C}, 40^{\circ} \mathrm{C}, 50^{\circ} \mathrm{C}, 60^{\circ} \mathrm{C}\right.$, $70^{\circ} \mathrm{C}$ and $\left.80^{\circ} \mathrm{C}\right)$. Different substrate concentrations $(0.5 \%, 1.0 \%, 1.5 \%$ and $2.0 \%)$ and incubation periods $(2,4,6$ and $24 \mathrm{hrs})$ were used to determine the optimum condition to produce $\mathrm{N}$-acetylglucosamine. Results showed that crude intracellular chitinase had an optimum $\mathrm{pH}$ of 5 with chitinase activity of $4.16 \pm 0.07 \mathrm{U} / \mathrm{mL}$ and optimum temperature of $60^{\circ} \mathrm{C}$ with chitinase activity of $4.22 \pm 0.07 \mathrm{U} / \mathrm{mL}$. The optimum substrate concentration obtained was $0.5 \%$ and the optimum incubation period obtained was $6 \mathrm{hrs}$ with about $961.67 \pm 9.13 \mathrm{ppm} N$-acetylglucosamine produced. Semi pure intracellular chitinase had an optimum $\mathrm{pH}$ of 4 with chitinase activity of $4.75 \pm 0.09 \mathrm{U} / \mathrm{mL}$ and optimum temperature of $50^{\circ} \mathrm{C}$ with chitinase activity of $5.03 \pm 0.08 \mathrm{U} / \mathrm{mL}$. The optimum substrate concentration obtained was $1.5 \%$ and the optimum incubation period obtained was $4 \mathrm{hrs}$ with about $1150.56 \pm 12.55 \mathrm{ppm} \mathrm{N}$-acetylglucosamine produced.
\end{abstract}

\section{Introduction}

Chitin is the most abundant natural amino polysaccharide that consists of $\mathrm{N}$-acetylglucosamine monomers attached to each other via $\beta(1,4)$ glycosidic linkages (Robiah, 2015). Chitin is also non-toxic, biodegradable and biocompatible in nature (Anitha et al., 2014). Chitin is very widely distributed, especially in animals. Higher concentrations up to $85 \%$ of chitin are found in Arthropoda such as shrimps (Savitri et al., 2010). The exoskeleton of Penaeus monodon shrimp contains up to $10 \%$ chitin, up to $40 \%$ proteins and 45 $50 \%$ minerals. The extraction of chitin from shrimp shells involves two steps, including demineralization and deproteinization process, which can be conducted by chemical and biological method (Arbia et al., 2012).

Glucosamine is the end hydrolytic product of chitin that can be obtained through chemical and enzymatic hydrolysis. Glucosamine, in the form of glucosamine sulfate, glucosamine hydrochloride, or Nacetylglucosamine is extensively consumed as a dietary supplement to treat osteoarthritis, back pain and knee pain. Glucosamine sulfate and glucosamine hydrochloride pose some defects including harsh hydrolysis conditions as both are obtained through chemical hydrolysis of chitin. To overcome it, glucosamine can be obtained through enzymatic hydrolysis of chitin using chitinase (Wang et al., 2008).

Even though chitinase can be obtained from many sources, chitinase of filamentous fungi have shown to have higher activity levels than those of plants and bacteria (Wang and Yang, 2007). Chitinolytic fungi include Trichoderma, Mucor, Beauveria, Aspergillus and Penicillium (Brzezinska et al., 2014). Fungi used in this research was Mucor circinelloides isolated from previous research by Veronica (2018), which showed high chitinolytic activity. Fungi could produce chitinase both extracellularly and intracellularly (Yamazaki et al., 
2007), but intracellular chitinase from fungi has not been studied extensively.

Moreover, to produce $\mathrm{N}$-acetylglucosamine, chitinase activity is affected by several factors such as substrate concentration, temperature, $\mathrm{pH}$ and fermentation time (Hao et al., 2012). Therefore, the objectives of this research were to determine the optimum $\mathrm{pH}$, temperature, substrate concentration and incubation period to produce $\mathrm{N}$-acetylglucosamine using crude and semi pure intracellular chitinase extracted from $M$. circinelloides.

\section{Materials and methods}

\subsection{Materials and equipment}

Materials used in this research were chitin isolated from shrimp shells of Penaeus monodon obtained from PT. Lola Mina located at Muara Baru, Jakarta, Indonesia, Mucor circinelloides culture obtained from Veronica (2018) previous study, Potato Dextrose Agar (PDA), Potato Dextrose Broth (PDB), Bradford reagent, bovine serum albumin (BSA), Sigma-Aldrich DNS (3,5Dinitrosalicylic acid) reagent, Sigma-Aldrich Nacetylglucosamine standard, $70 \%$ ammonium sulfate, sodium phosphate dibasic $\left(\mathrm{Na}_{2} \mathrm{HPO} 4\right)$, magnesium sulfate $\left(\mathrm{MgSO}_{4}\right), 37 \%$ hydrochloric acid $(\mathrm{HCl})$, sodium hydroxide $(\mathrm{NaOH})$, distilled water, phosphate buffer $(\mathrm{pH}$

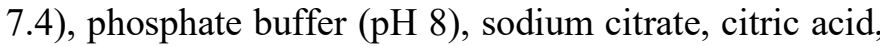
monosodium dihydrogen orthophosphate $\left(\mathrm{NaH}_{2} \mathrm{PO}_{4}\right)$, glycine and potassium sodium tartrate.

\subsection{Extraction of intracellular chitinase of $M$ circinelloides}

The extraction of chitinase from $M$. circinelloides was done based on the method by Struszczyk et al. (2008) with modifications. Firstly, $3 \mathrm{~mL}$ of mold culture was added to $300 \mathrm{~mL}$ of PDB that have been fortified with $0.5 \% \mathrm{Na}_{2} \mathrm{HPO}_{4}, 0.5 \% \mathrm{MgSO}_{4}$, and $0.5 \%$ chitin and incubated at room temperature for 2 days using shaker. After incubation, media was then centrifuged at 3500 rpm for 10 mins at $4^{\circ} \mathrm{C}$. The precipitate obtained was suspended in $4 \mathrm{~mL}$ of lysis buffer per $80 \mathrm{~mL}$ of culture. The mixture was then sonicated using $47 \mathrm{kHz}$ for 10 mins and centrifuged at $3500 \mathrm{rpm}$ for 10 mins. The supernatant produced was crude intracellular enzyme.

To purify the enzyme, the supernatant was further added with $70 \%$ ammonium sulfate with ratio $1: 1$ and left to settle for $18 \mathrm{hrs}$. Then it was centrifuged at 3500 rpm for 10 mins. The precipitate was then dissolved in 8 $\mathrm{mL}$ of $0.05 \mathrm{M}$ phosphate buffer $(\mathrm{pH} 8)$ per $150 \mathrm{~mL}$ initial culture. The solution obtained was semi pure intracellular chitinase.

\subsection{Determination of optimum ph and temperature of chitinase}

The determination of optimum $\mathrm{pH}$ and temperature of chitinase was done based on Annamalai et al. (2011) with modifications. To determine the optimum $\mathrm{pH}$, the substrate was prepared by mixing buffer solution of $\mathrm{pH}$ $3,4,5,6,7,8$ and 9 with $1 \%$ chitin. The substrate was then sterilized. About $1 \mathrm{~mL}$ of the substrate was added with $1 \mathrm{~mL}$ of crude or semi pure chitinase and incubated for 1 hour at room temperature. The mixture was centrifuged at $13000 \mathrm{rpm}$ for 5 mins. The chitinase activity was then analyzed using the DNS method.

To determine the optimum temperature, $1 \mathrm{~mL}$ of the substrate with optimum $\mathrm{pH}$ obtained was added with 1 $\mathrm{mL}$ of crude or semi pure chitinase and incubated at different temperatures $\left(30^{\circ} \mathrm{C}, 40^{\circ} \mathrm{C}, 50^{\circ} \mathrm{C}, 60^{\circ} \mathrm{C}, 70^{\circ} \mathrm{C}\right.$ and $80^{\circ} \mathrm{C}$ ) for $1 \mathrm{hr}$. It was then centrifuged at $13000 \mathrm{rpm}$ for 5 mins. The chitinase activity was then analyzed using the DNS method.

\subsection{Determination of optimum substrate concentration and incubation period of chitinase}

Determination of optimum substrate concentration and incubation period of chitinase was done based on the method done by Annamalai et al. (2011) with modifications. The substrate of different concentrations $(0.5 \%, 1 \%, 1.5 \%$ and $2 \%)$ with optimum $\mathrm{pH}$ were each added with $1 \mathrm{~mL}$ of crude or semi pure chitinase and incubated at optimum temperature at different incubation periods (2, 4, 6 and $24 \mathrm{hrs})$. After incubated, it was centrifuged at $13000 \mathrm{rpm}$ for 5 mins. $\mathrm{N}$ acetylglucosamine obtained was then analyzed using the DNS method.

\subsection{Chitinase activity and $\mathrm{N}$-acetylglucosamine concentration analyses}

The chitinase activity was analyzed using the DNS method (Jha and Modi, 2017). An aliquot (1 mL) of the sample was then added with $1 \mathrm{~mL}$ of DNS reagent and 1 $\mathrm{mL}$ of $4 \%$ potassium sodium tartrate. The mixture was then heated in a boiling water bath for 15 mins to stop the reaction in the mixture. About $1 \mathrm{~mL}$ of the heated mixture was then diluted with $4 \mathrm{~mL}$ of water. The diluted mixture was then measured at $540 \mathrm{~nm}$ using UV-Vis spectrophotometer to determine its $\mathrm{N}$-acetylglucosamine concentration. A standard curve was prepared using Nacetylglucosamine standard with concentrations of 200 , 400, 600, 800 and $1000 \mathrm{ppm}$. Furthermore, $1 \mu \mathrm{mol}$ of $N$ acetylglucosamine produced by the chitinase is defined as one unit $(U)$ of chitinase activity. 


\subsection{Data analysis}

All data obtained from the experiment were analyzed using SPSS version 22.

\section{Results and discussion}

\subsection{Characteristics of isolated chitin}

The isolated chitin used in this research was obtained through demineralization and deproteinization process of shrimp shells. The yield of isolated chitin was $6.42 \pm 0.07 \%$. According to Arbia et al. (2012), shrimp shells contain up to $10 \%$ of chitin depending on the species of the shrimps. Moreover, the ash content of isolated chitin $0.23 \pm 0.02 \%$, lower than previous research done by Poeloengasih et al. (2008), which was about $2.34 \%$. It is because the demineralization process in this research was about $2 \mathrm{hrs}$, longer than research by Poeloengasih et al. (2008), which was 15 mins. The protein content of isolated chitin was $0.8 \pm 0.02 \%$, lower when compared to those obtained by Islam et al. (2016) which was $1.8 \%$. The difference in chitin's protein content could be caused by the difference in temperature and time used in the deproteinization process. In this research, the temperature used was $80^{\circ} \mathrm{C}$ for $2 \mathrm{hrs}$, whereas in research by Islam et al. (2016), the temperature used was $70-75^{\circ} \mathrm{C}$ for $1 \mathrm{hr}$. Temperature is an important parameter that affects chitin's purity as the reaction rate in the deproteinization process increases with increasing temperature (Percot et al., 2003). Lower ash content and protein content of isolated chitin in this research showed that deproteinization and demineralization process was done effectively. Furthermore, to ensure that chitin was obtained from these processes, measurement of the degree of deacetylation (DD) was also done. The degree of deacetylation (DD) of chitin obtained in this research was $23.06 \%$. According to Arbia et al. (2012), chitin had a DD value of less than $50 \%$, while chitosan had a DD value of higher than $50 \%$.

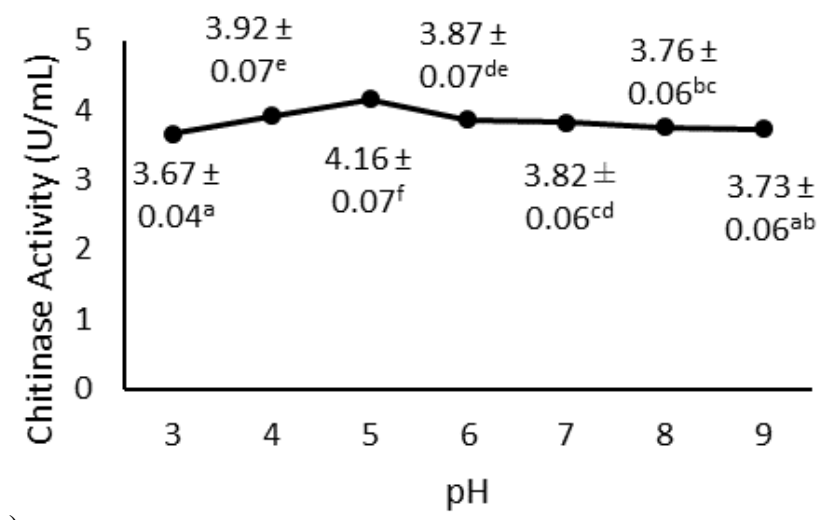

(a)

Figure 1. Effect of pH on (a) crude intracellular chitinase and (b) semi pure intracellular chitinase activity. Values are expressed as mean \pm standard deviation. Values with different superscript letters indicate significant difference $(\mathrm{p} \leq 0.05)$.

Effect of $\mathrm{pH}$ on crude and semi pure intracellular chitinase obtained on this research could be seen in Figure 1 (a) and (b), respectively. The statistical results using ANOVA showed that there was a significant effect of $\mathrm{pH}$ on chitinase activity $(\mathrm{p} \leq 0.05)$.

Crude intracellular chitinase activity in this research showed to be at its optimum at $\mathrm{pH} 5$ with the enzyme activity of $4.16 \pm 0.07 \mathrm{U} / \mathrm{mL}$. Sharaf (2005) reported that fungi mostly secrete its chitinase in acidic conditions. Brzezinska et al. (2014) mentioned that optimum $\mathrm{pH}$ for chitinase activity was around 5-8. Priya et al. (2016) also found that the chitinase activity of Beauveria bassiana and Trichoderma harzianum were shown to be optimum at $\mathrm{pH} 5.5$ and 6.5 , with the chitinase activity of $5.08 \mathrm{U} /$ $\mathrm{mL}$ and $6.4 \mathrm{U} / \mathrm{mL}$, respectively. However, crude intracellular chitinase activity in this research was comparable its crude extracellular chitinase activity which was $4.38 \pm 0.06 \mathrm{U} / \mathrm{mL}$ (Halim et al., 2019).

On the other hand, the enzyme activity of semi pure chitinase obtained in this research was optimum at $\mathrm{pH} 4$ with chitinase activity of $4.75 \pm 0.09 \mathrm{U} / \mathrm{mL}$. This indicates that the enzyme activity of semi pure chitinase obtained was 1.14 times higher than that of crude chitinase obtained. Kim et al. (2003) and Pratiwi et al. (2015) found that the chitinase purified using $75 \%$ and $80 \%$ ammonium sulfate had an activity up to 1.90 and 2.21 times higher than before it was purified, respectively.

The optimum $\mathrm{pH}$ of semi pure chitinase obtained in this research showed a slight difference when compared to the optimum $\mathrm{pH}$ of crude chitinase $(\mathrm{pH}=5)$. Pandey et al. (2017) reported that optimum $\mathrm{pH}$ depends on the degree of purity of the enzyme. Martinez et al. (2007) also mentioned that purified chitinase from Trichoderma atroviride had an optimum $\mathrm{pH}$ of 4.0.

Another factor that contributes to enzyme activity is temperature. Effect of temperature on crude and semi

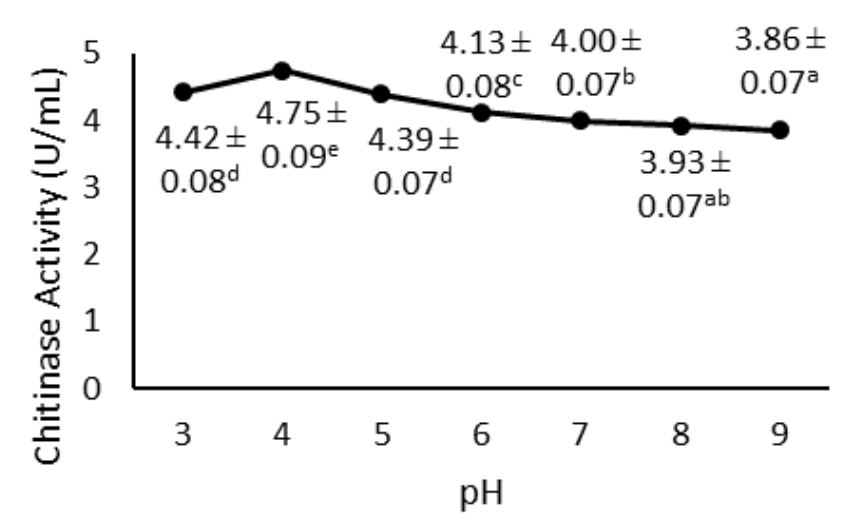

(b) 
pure intracellular chitinase obtained on this research could be seen on Figure 2 (a) and (b), respectively. The statistical results using ANOVA showed that there was a significant effect of temperature on chitinase activity $(\mathrm{p} \leq 0.05)$.

Figure 2 (a) shows that the optimum temperature for crude chitinase activity obtained in this research was at $60^{\circ} \mathrm{C}$ with chitinase activity of $4.22 \pm 0.07 \mathrm{U} / \mathrm{mL}$. This is in accordance with the theory by Pandey et al. (2017) in which the optimum temperature for most fungal chitinase activity is within 40 to $60^{\circ} \mathrm{C}$. Moreover, De Marco et al. (2004) and Chen et al. (2013) found that chitinases obtained from Trichoderma harzianum and Rhizopus oryzae had an optimum temperature of $60^{\circ} \mathrm{C}$.

Meanwhile, the optimum temperature for the activity of semi pure chitinase was at $50^{\circ} \mathrm{C}$ with chitinase activity of $5.03 \pm 0.08 \mathrm{U} / \mathrm{mL}$. Binod et al. (2005) and Kopparapu et al. (2012) found that the activity of purified fungal chitinases from Penicillium aculeatum and Paecilomyces thermophila were optimum at $50^{\circ} \mathrm{C}$. The optimum temperature obtained for the semi-pure chitinase was different from that obtained for the crude chitinase because the optimum temperature of chitinase is dependent on the degree of purity of enzyme (Pandey et al., 2017).

\subsection{Optimum substrate concentration and incubation period on $\mathrm{N}$-acetylglucosamine production}

To determine the optimum substrate concentration and incubation period in producing $\mathrm{N}$ acetylglucosamine, both the optimum $\mathrm{pH}$ and temperature obtained for crude and semi pure intracellular chitinase were used. Figures 3 and 4 show the effect of substrate concentration and incubation period on $\mathrm{N}$-acetylglucosamine concentration using crude intracellular chitinase and semi pure intracellular chitinase, respectively.

Statistical results showed that both substrate concentration and incubation period and their interaction

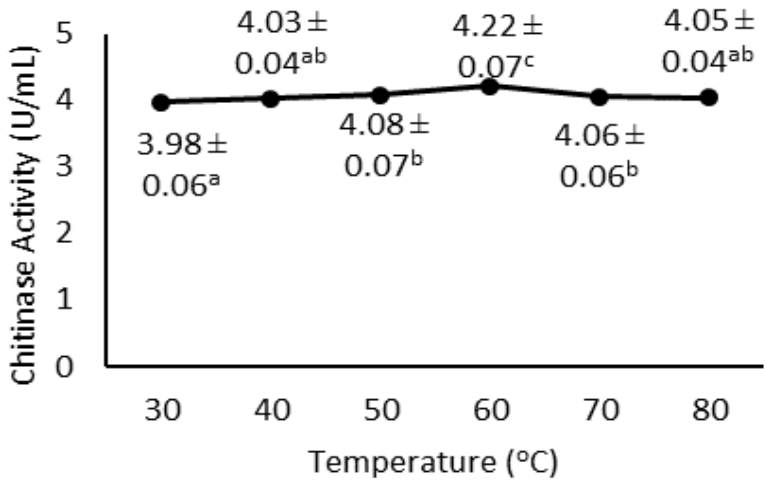

(a)

Figure 2. Effect of temperature on (a) crude intracellular chitinase and (b) semi pure intracellular chitinase activity. Values are expressed as mean \pm standard deviation. Values with different superscript letters indicate significant difference $(p \leq 0.05)$. gave significant effect on $\mathrm{N}$-acetylglucosamine produced $(p \leq 0.05)$. Using crude intracellular chitinase, the highest $\mathrm{N}$-acetylglucosamine concentration was obtained at $0.5 \%$ substrate concentration- $6 \mathrm{hrs}$ incubation period with the concentration of $961.67 \pm 9.13 \mathrm{ppm}$. Moreover, in the reaction using semi pure intracellular chitinase the highest $\mathrm{N}$-acetylglucosamine concentration was obtained at $1.5 \%$ substrate concentration- 4 hrs incubation period with a concentration of $1150.56 \pm 12.55 \mathrm{ppm}$.

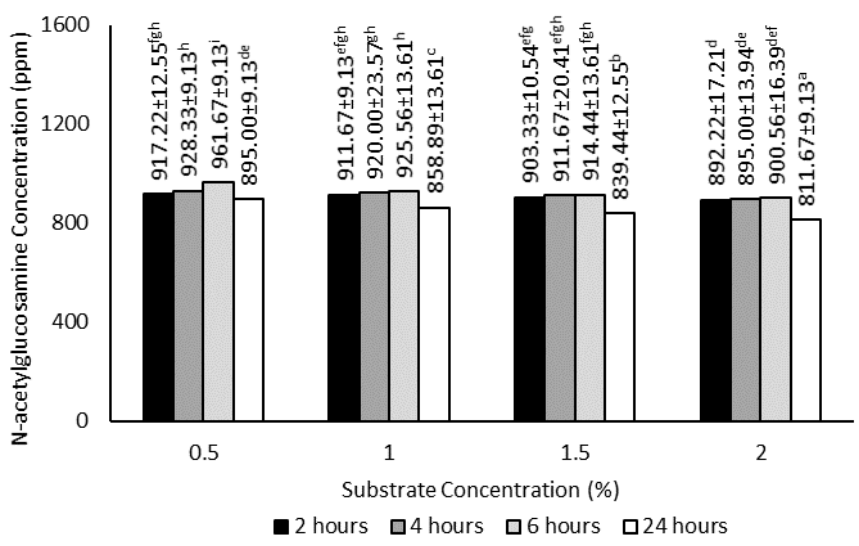

Figure 3. Effect of substrate concentration and incubation period on $\mathrm{N}$-acetylglucosamine concentration using crude intracellular chitinase. Values are expressed as mean \pm standard deviation. Values with different superscript letters indicate significant difference $(p \leq 0.05)$.

According to Poedjiadi and Supriyanti (2006), in a low concentration, the substrate is only partially bound to the active site of the chitinase. If the concentration is increased, the amount of substrate bound to the active site of the chitinase increases. However, the addition of a high concentration of substrate in the enzymatic reaction can lead to a saturated condition (Hendri et al., 2007). Longer incubation period could also decrease the Nacetylglucosamine production due to the denaturation of enzymes during the reaction or inhibition from $\mathrm{N}$ acetylglucosamine as the product (Sukprasirt and Wititsuwannakul, 2014).

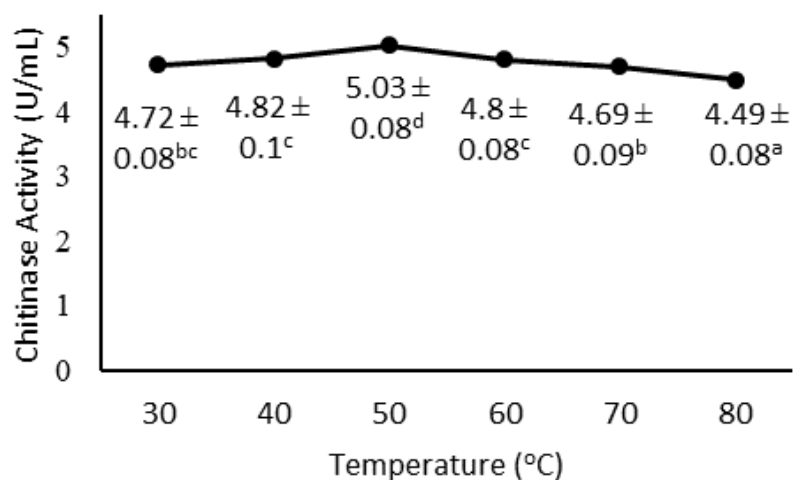

(b) 


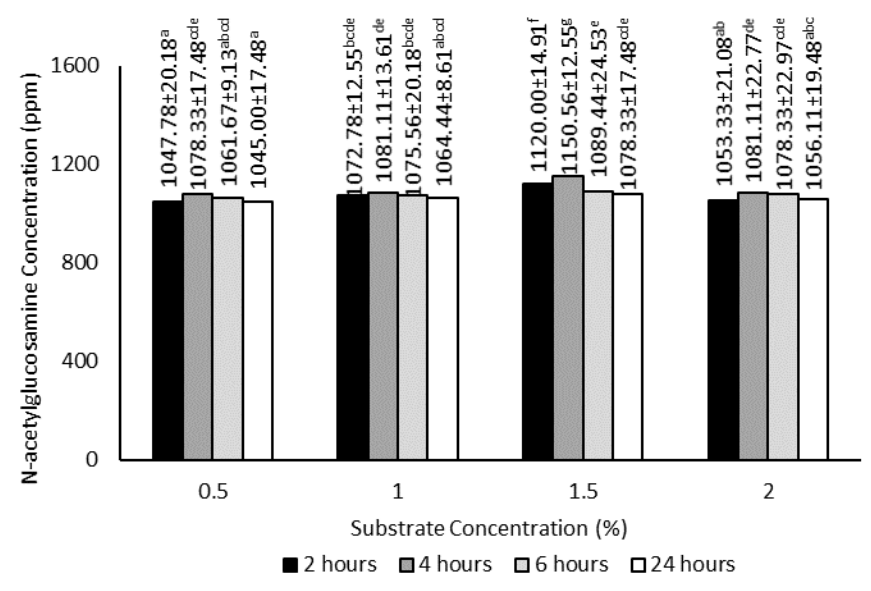

Figure 4. Effect of substrate concentration and incubation period on $\mathrm{N}$-acetylglucosamine concentration using semi pure intracellular chitinase. Values are expressed as mean \pm standard deviation. Values with different superscript letters indicate significant difference $(\mathrm{p} \leq 0.05)$.

Results in this research show that semi pure intracellular chitinase could produce higher $\mathrm{N}$ acetylglucosamine concentration in a shorter incubation period but it required a higher concentration of substrate. However, the concentration of $\mathrm{N}$-acetylglucosamine produced using intracellular chitinase from $M$. circinelloides is also lower compared to its extracellular chitinase, which can produce about $2195.83 \pm 15.14 \mathrm{ppm}$ of $\mathrm{N}$-acetylglucosamine after $2 \mathrm{hrs}$ of incubation period in $1.5 \%$ substrate concentration (Halim et al., 2019). Another research by Herdyastuti and Cahyaningrum (2017) using chitinase from Pseudomonas sp. with amorphous modified chitin as a substrate, showed higher concentration of $\mathrm{N}$-acetylglucosamine produced, i.e. about $10950 \mathrm{ppm}$, at incubation period of $8 \mathrm{hrs}$ and about $22500 \mathrm{ppm}$, at $1.2 \%$ substrate concentration.

\section{Conclusion}

Crude intracellular chitinase of $M$. circinelloides had an optimum $\mathrm{pH}$ of 5 with chitinase activity of $4.16 \pm 0.07$ $\mathrm{U} / \mathrm{mL}$ and optimum temperature of $60^{\circ} \mathrm{C}$ with chitinase activity of $4.22 \pm 0.07 \mathrm{U} / \mathrm{mL}$. The highest Nacetylglucosamine concentration was obtained at $0.5 \%$ substrate concentration with $6 \mathrm{hrs}$ of incubation period with the concentration of $961.67 \pm 9.13 \mathrm{ppm}$. Semi pure intracellular chitinase of $M$. circinelloides had an optimum $\mathrm{pH}$ of 4 with chitinase activity of $4.75 \pm 0.09 \mathrm{U} /$ $\mathrm{mL}$ and optimum temperature of $50^{\circ} \mathrm{C}$ with chitinase activity of $5.03 \pm 0.08 \mathrm{U} / \mathrm{mL}$. The highest $\mathrm{N}$ acetylglucosamine concentration was obtained at $1.5 \%$ substrate concentration with $4 \mathrm{hrs}$ of incubation period with the concentration of $1150.56 \pm 12.55 \mathrm{ppm}$.

\section{Conflict of Interest}

The authors declare no conflict of interest.

\section{Acknowledgments}

This research was financially supported by the Center of Research and Community Development, Universitas Pelita Harapan through Research Project no: $\mathrm{P}-0004 / \mathrm{FaST} / \mathrm{I} / 2018$.

\section{References}

Anitha, A., Sowmya, S., Kumar, P.T.S. and Deepthi, S. (2014). Chitin and chitosan in selected biomedical applications. Progress in Polymer Science, 39(9), 1644-1667.

https://doi.org/10.1016/ j.progpolymsci.2014.02.008

Annamalai, N., Rajeswari, M.V., Vijayalakshmi, S. and Balasubramanian, T. (2011). Purification and characterization of chitinase from Alcaligenes faecalis AU02 by utilizing marine wastes and its antioxidant activity. Annals of Microbiology, 61(4), 801-807. https://doi.org/10.1007/s13213-011-0198-5

Arbia, W., Arbia, L., Adour, L. and Amrane, A. (2012). Chitin extraction from crustacean shells using biological methods - a review. Food Technology and Biotechnology, 51(1), 12-25.

Binod, P., Pusztahelyi, T., Nagy, V., Sandhya, C., Szakacs, G. and Pocsi, I. (2005). Production and purification of extracellular chitinases from Penicillium aculeatum NRRL 2129 under solid-state fermentation. Enzyme and Microbial Technology, 36 (8), 880-887. https://doi.org/10.1016/ j.enzmictec.2004.12.031

Brzezinska, M.S., Jankiewicz, U., Butkowska, A. and Walczak, M. (2014). Chitinolytic microorganisms and their possible application in environmental protection. Current Microbiology, 68(1), 71-81. https://doi.org/10.1007/s00284-013-0440-4

Chen, W.M., Chen, C.S. and Jiang, S.T. (2013). Purification and characterization of an extracellular chitinase from Rhizopus oryzae. Journal of Marine Science and Technology, 21(3), 361-366.

De Marco, J.L., Valadares-Inglis, M.C. and Felix, C.R. (2004). Purification and characterization of an nacetylglucosaminidase produced by a Trichoderma harzianum strain which controls Crinipellis perniciosa. Applied Microbiology and Biotechnology, 64(1), 70-75. https://doi.org/10.1007/ s00253-003-1490-5

Halim, Y., Hardoko and Pengalila, R.F. (2019). Determination of optimal fermentation condition for $\mathrm{N}$-acetylglucosamine production using Mucor circinelloides Extracellular Chitinase. Journal of Fisheries Sciences, 21(2), 105-110. https:// doi.org/10.22146/jfs.45859

Hao, Z., Yujie, C., Xiangru, L., Zhang, X., Fang, Z. and Zhang, D. (2012). Optimization of nutrition factors on chitinase production from a newly isolated 
Chitiolyticbacter meiyuanensis SYBC-H1. Brazilian Journal of Microbiology, 43(1), 177-186. https:// doi.org/10.1590/S1517-83822012000100019

Hendri, J., Wardana, Suka, I.G. and Laila, A. (2007). Penentuan kadar $\mathrm{Ca}$ dan $\mathrm{Mg}$ pada hasil demineralisasi optimum kulit udang windu secara gravimetri dan spektroskopi serapan atom dimuat. Jurnal Sains MIPA, 13(2), 93-99. [In Bahasa Indonesia].

Herdyastuti, N. and Cahyaningrum, S.E. (2017). Analysis of $\mathrm{N}$-acetylglucosamine from enzymatic degradation of amorphous chitin. Rasayan Journal Chemistry, 10(1), 226-233.

Islam, S., Khan, M. and Alam, A. (2016). Production of chitin and chitosan from shrimp shell wastes. Journal of the Bangladesh Agricultural University, 14(2), 253-259. https://doi.org/10.3329/ jbau.v14i2.32701

Jha, S.C. and Modi, H.A. (2017). Comparative analysis of chitinase activity by four different assays from soil born Actinomycetes, presented at the $4^{\text {th }}$ International Conference on Multidisciplinary Research and Practice, Ahmedabad, 2017. Gurgaon, India: Research and Scientific Innovation Society.

Kim, K., Yang, Y. and Kim, J. (2003). Purification and characterization of chitinase from Streptomyces sp. M-20. Journal of Biochemistry and Molecular Biology, 36(2), 185-189. https://doi.org/10.5483/ BMBRep.2003.36.2.185

Kopparapu, N.K., Zhou, P., Zhang, S., Yan, Q., Liu, Z. and Jiang, Z. (2012). Purification and characterization of a novel chitinase gene from Paecilomyces thermophila expressed in Escherichia coli. Carbohydrate Research, 347(1), 155-160. https://doi.org/10.1016/j.carres.2011.11.002

Martinez, J.P., Falomir, M.P. and Gozalbo, D. (2014). Chitin: A Structural Biopolysaccharide with Multiple Applications. New Jersey: John Wiley and Sons Ltd. https:// doi.org/10.1002/9780470015902.a0000694.pub3

Pandey, A., Negi, S. and Soccol, C.R. (2017). Production, Isolation and Purification of Industrial Products. The Netherlands: Elsevier.

Percot, A., Viton, C. and Domard, A. (2003). Optimization of chitin extraction from shrimp shells. Biomacromolecules, 4(1), 12-18. https:// doi.org/10.1021/bm025602k

Poedjiadi, A. and Supriyanti, T. (2006). Dasar-dasar Biokimia Edisi Revisi. Jakarta: UI-Press.

Poeloengasih, C.D., Hernawan and Angwar, M. (2008). Isolation and characterization of chitin and chitosan prepared under various processing times. Indonesian Journal of Chemistry, 8(2), 189-192. https:// doi.org/10.22146/ijc.21635
Pratiwi, R.S., Susanto, T.E., Wardani, Y.A.K. and Sutrisno, A. (2015). Enzim kitinase dan aplikasi di bidang industri: kajian pustaka. Jurnal Pangan dan Agroindustri, 3(3), 878-887.

Priya, D., Ramesh, B.N.G, Sneka, S. and Karthikeyan, S. (2016). Enhancement and detection of chitinase enzyme of fungus for the eradication of pests. International Journal of Science Technology and Engineering, 3(2), 169-172.

Robiah, N. (2015). Mapping the activity of chitinase enzymes and deacetylase chitin of isolating Actinomycetes ANL-4 in chitin degradation during incubation time for $24 \mathrm{hrs}$. Lampung: Lampung University, BSc. Thesis.

Savitri, E., Soeseno, N. and Adiarto, T. (2010). Sintesis kitosan, poli(2-amino-2-deoksi-D-Glukosa), skala Pilot Project dari limbah kulit udang sebagai bahan baku alternatif pembuatan biopolymer, presented Seminar Nasional Teknik Kimia, Yogyakarta, 2010. Yogyakarta: UPN “Veteran” Yogyakarta. [In Bahasa Indonesia].

Sharaf, E.F. (2005). A potent chitinolytic activity of Alternaria alternate isolated from Egyptian black sand. Polish Journal of Microbiology, 54(2), 145151.

Struszczyk, K., Szczesna-Antczak, M., Walczak, M. and Antczak, T. (2008). Isolation and purification of intracellular chitosanolytic enzymes of Mucor circinelloides. Progress on Chemistry and Application of Chitin, 78(1), 107-117. https:// doi.org/10.1016/j.carbpol.2009.04.010

Sukprasirt, P. and Wititsuwannakul, R. (2014). A chitinolytic endochitinase and $\beta-\mathrm{N}-$ acetylglucosaminidase-based system from hevea latex in generating $\mathrm{N}$-acetylglucosamine from chitin. Phytochemistry, 104, 5-11. https://doi.org/10.1016/ j.phytochem.2014.04.001

Veronica. (2018). Uji aktivitas kitinolitik kapang yang diisolasi dari kulit udang windu (Penaeus monodon). Tangerang: Universitas Pelita Harapan, BSc. Thesis. [In Bahasa Indonesia].

Wang, J., Zhang, J., Song, F., Gui, T. and Xiang, J. (2015). Purification and characterization of chitinases from ridgetail white prawn Exopalaemon carinicauda. Molecules, 20(2), 1955-1967. https:// doi.org/10.3390/molecules20021955

Wang, L. and Yang, S. (2007). Bioprocessing for ValueAdded Products from Renewable Resources. New York: Elsevier.

Yamazaki, H., Yamazaki, D., Takaya, N., Takagi, M., Ohta, A. and Horiuchi, H. (2007). A chitinase gene, chiB, involved in the autolytic process of Aspergillus nidulans. Current Genetics, 51(2), 89-98. https:// doi.org/10.1007/s00294-006-0109-7 